\title{
U.N.E.S.C.O., (V.V.O.) EN CHRISTENDOM
}

Toe in die Volksraad 'n tydjie gelede die pos Onderwys onder bespreking was, het die minister van Onderwys, dr. A. J. Stals, volgens die persverslag gesê dat hy ietwat skepties staan teenoor die V.V.O. se onderwys- en kultuurorganisasie (Unesco) en dat hy nog nie vry is van alle argwaan dienaangaande nie. Die minister het dan ook die vraag opgewerp watter nut Suid-Afrika as lid van hierdie organisasie kan verwag. Voortgaande het hy as sy oortuiging uitgespreek dat daar'n wye gebied is waarop hierdie organisasie van nut in die wêreld kan wees, maar dat die misbruik wat in die verlede gemaak is verhoed moet word, Tot sover die persverslag.

Nou dat die saak van U.N.E.S.C.O., of onverkort: die United Nations Educational ,Scientific and Cultural Organisation weer aan die orde gestel is, ook in Suid-Afrika, kan dit sy nut hê om in die algemeen enkele opmerkinge te maak oor die strewe van hierdie organisasie en sy geestelike vader, die V.V.O., om daarna ons prinsipiële kritiek op hierdie strewe te gee.

Om die strewe van hierdie organisasie te verstaan, moet dit gesien word in die raamwerk van die tyd waarin ons lewe, en teen die agtergrond van die pas afgelope wêreldbrand. Ons lewe in 'n tyd waarin die volke van die wêreld met internasionale bande aan mekaar verbind is. Die moontlikhede van wêreldvervoer en wêreldverkeer het die mag van die mensdom reusagtig vergroot. So'n ontwikkeling kan dan ook nie meer gestuit word nie, maar mag ook nie gestuit word nie, omdat dit ongetwyfeld behoort tot die kultuuropdrag van die mensheid. 
Daarmee is egter die laaste woord nog nie gesê nie. Immers magsmoontlikheid in die hande van die mensheid sluit ook altyd die moontlikheid van 'n verkeerde gebruik daarvan in. Is dit miskien die misbruik van hierdie mag, waarna die minister verwys het? Hoe dit ook sy, dit lê voor die hand dat die leiers van die volke soek na middele en weë om die internasionale chaos op politieke gebied te orden en 'n liggaam te skep wat gesag bo die afsonderlike state besit. Aan so'n organisasie is daar altyd twee kante Aan die een kant kan dit die so noodsaaklike ordening bring, maar aan die ander kant bestaan die moontlikheid van 'n eweeens wêreldomspannende tirannie, deurdat die wêreldmag in die hande van een of min state gelê word.

Op die oomblik is ons nog allermins sover dat ons die oorlog uitgeban het. Die Volkebond was 'n poging in dié rigting en hierdie poging is voortgesit deur die V.V.O. Vir die goeie funksionering van so 'n liggaam is meer nodig as net die bestaan van die liggaam. Daar moet ook by die onderdane 'n gevoel van saamhorigheid wees, en waar dit ontbreek daar dreig so 'n organisasie om in onmag en wanorde te versink, deurdat die verskille tussen die lede die oorhand kry oor dit wat hulle saambind.

Maar daar kom nog iets by. Wil die mens die oorlog wat die duidelikste gevolg en die simptoom van die internasionale chaos is, uitban. dan moet die mens ook by die volke 'n vredeliewende gesindheid kweek. Nou is dit juis by hierdie ankweek van 'n vredeliewende gesindheid dat ons in aanraking kom met etiese en godsdienstige kwessies en dis juis op hierdie gebiede wat Unesco wil optree.

Reeds in 1942 is die eerste pogings onderneem om te kom tot die oprigting van hierdie organisasie, en na die kapitulasie van die agressiestate het dit sy finale beslag gekry. Byna alle lande is lid van hierdie organisasie, uitgesonder die agressiestate, enkele minder betekende Suid-Amerikaanse republieke en wat belangrik is: Rusland is nie lid nie. Dat hierdie organisasie spreek tot die verbeelding van die groot publiek of dat sy resultate groot opsien baar, kan tot dusver nog nie beweer word nie. Wel is 'n paar groot byeenkomste gehou, waarop ook Suid-Afrika verteenwoordig was, en verskyn daar 'n orgaan, ,Courier", maar die effek van dit alles is, omgekeerd eweredig aan die groot hoofdoel wat die oprigting hulle gestel het: die bevordering van die wêreldvrede.

Die taak wat Unesco op hom geneem het kan in 'n sekere sin vergelyk word met dié van die eertydse U.N.N.R.A. op die gebied van die voedselvoorsiening aan die lande wat gebrek gely het. Unesco wil hulp bring daar waar state en lande gely het op kulturele en opvoedkundige terrein. In hierdie opsig gaan sy aksie uit na die hernuwing van vernietigde biblioteke soos die biblioteek van Leuven, wat in die twee agtereen volgende 
wêreldoorloë die slagoffer geword het van die furor Teutonicus, tot die verskaffing van penne, potlode en papier aan die volke, waar die onderwys ly onder die gebrek aan hierdie onontbeerlike materiaal. In hierd e opsig kan 'n mens hulle alleen maar sukses toewens.

Maar daar staan nog ander moontlikhede oop. Die organisasie wil internasionale kontak bevorder deur uitwisseling van leerlinge, studente, onderwysers en professore, deur die verspreiding en verbreiding van die kulturele en wetenskaplike besit van die afsonderlike state, deur 'n bevredigende internasionale reëling van outeursregte en wat dies meer sy. Maar hierdie hele aksie is ondergeskik aan die hoofdoel: die verdediging van die vrede. Hoe wil die organisasie hierdie doel bereik? In hierdie verband kan ons nie beter doen as om enkele vry vertaalde sitate uit die reglement aan te haal nie.

Die reglement begin met die verklaring dat aangesien die oorlog begin in die gees van die mens, die verdediging van die vrede in die gees van die mens opgebou moet word. Onbekendheid met mekaar se lewenswyse was die hele geskiedenis deur 'n algemene rede van wantroue tussen die volke, waardeur al te dikwels hulle verskille gelei het tot die uitbreek van oorloë. Die groot en verskriklike oorlog wat pas geëindig het, was moonlik vanweë die ontkenning van die demokratiese prinsiepes van die waardigheid, die gelykheid en die wedersydse eerbied vir die menslike persoonlikheid. In die plek daarvan het deur die propagenda gekom onwetenheid en vooroordeel en die leer van die ongelykheid van mense en rasse. Daarteenoor moet gestel word 'n wye verspreiding van die kultuur en die opvoeding van die mensheid tot regverdigheid, vryheid en vrede wat noodsaaklik is vir die waardigheid van die mens. Hierdie verspreiding van die kultuur en die opvoeding van die mensheid moet beskou word as 'n heilige plig, wat al die nasies moet vervul in 'n gees van wederkerige bystand en sorg. 'n Vrede wat uitsluitend gebaseer is op die politieke en ekonomiese ooreenkomste van regerings sal geen blywende vrede wees nie. Die vrede moet daarom gebaseer wees op die intellektuele en morele solidariteit van die mensdom.

Die bostaande is kortliks die grondgedagtes wat die basis vorm vir die strewe van Unesco en hierdie grondgedagtes vereis 'n prinsipiële analise en kritiek. Dit is baie juis gesien dat die oorlog sy oorsprong het in die gees van die mens. Maar die rede dat dit geleë is in die feit dat die volke mekaar nie genoeg ken en waardeer nie, word onvoldoende gepeil. Met die selfliefde en die selfdiens, die hoofsondes van die mensheid, wat ons drywe tot al ons onvrede en in kollektiewe vorm tot oorlog, word hier geen rekening gehou nie. Nou val dit nie te ontken nie dat in bepaalde gevalle opsetlik aangemoedigde waardering van nabuurvolke en bevolkings- 
groepe moeilikhede en wrywinge kan verminder, net soos 'n doelbewuste negering in teenstelling met waardering, baie onheil gestig het. „Goodwill” kan in sulke gevalle baie goeie vrugte afwerp.

Omdat die kwaal onvoldoende onderken is, is ook die geneesmiddel onvoldoende. Die remedie is die vrye sirkulasie van ideë, maar die vraag is watter ideë. Almal? Dit kan tog nie, want dis tog 'n feit dat die ideogieë wat oor die wêreld verbrei word nou nie juis tot die vrede bygedra het nie. Inteendeel ons vind dat juis die ideë die mense in vyandelike kampe drywe. Maar selfs al sou die mens daarin slaag om 'n soort van algemene opvatting te kreëer dan was die onenigheid nog nie die wêreld uitgehelp nie. Die toestand het in Europa herhaaldelik bestaan, laastelik nog in die $19 \mathrm{e}$ ecu en min of meer in die begin van die 20 ste eeu, maar vrede het dit nie gewaarborg nie.

Die verklaring wat ons vry vertaal het, is deur en deur humanisties. Die leiers gaan van die opvatting uit dat die mens van nature goed is. As hy maar sy ideë verbrei en kenbaar maak aan hulle wat nog nie daarmee op die hoogte is nie, sal daar ' $n$ bevredigende resultaat uit voortvloei. Dit is ou bekende maar ook ouderwetse klanke. Die hele gedagtewëreld wat hier agter sit is afkomstig uit die Angelsaksiese en Amerikaanse kultuurmilieu waar die Humanisme in sy optimistiese vorm nog gedeeltelik die breë massas onder sy beslag het. Vandaar dat die mens ook so argeloos spreek oor die voordele van die opvoeding. Met trots word dan daarop gewys dat daar maatreëls getref is om ' $n$ end te maak aan die analfabetisme in Meksiko.Wie sou so iets nie toejuig nie, meer aan die anderkant moet 'n mens tog werklik baie naïef wees om hier goeds van te verwag vir die vrede. Ook word daar op gewys hoe in China die kuns van lees en skrywe die laaste jare toe geneem het, en die verwagting is dan dat die geletterde Chinese beter boere sal wees en aan die politiek sal deelneem. Was die Duitsers en die Japanese miskien nie geletterd genoeg nie? Verder word daar op gewys hoedat die ,morele basis van die vrede" - die trou aan die gegewe woord, die gemeenskaplike opvattings van die regte tussen nasies, die individuele regte van die mens-slag op slag verraai is. Hierdie morele basis kan alleen herstel word deur geduldige heropvoeding.

In derglike uitsprake wil ons graag waardeer wat daarin te waardeer is en dan vernaamlik die roep om regverdigheid en eerbied vir die menslike waardigheid en persoonlikheid. Dit is seker nie 'n kleinigheid in 'n wêreld waarin die geweld, wat op goddelose ideologieë gebaseer is, hom niks van hierdie waardes meer aantrek nie. Die Humanisme voer hier die pleit vir daardie oorblyfsel van die Christelike waardes wat hulle nog enigermate in ons menslike samelewing kon handhaaf. 
Maar- en dit ons prinsipiële en radikale kritiek-dieselfde Humanisme vergeet dat hierdie geestesbeweging juis meegehelp het om daardie Christelike waardes te devalueer en van hul Christelike sin te berowe, eerstens deur sy religieuse grondinstelling van die sekularisering van die Christelike skeppings-en vryheidsgedagte, en deur sy emansipering van die menslike persoonlikheid uit die religieuse afhanklikheid van die God van die openbaring; en twedens verloor dit uit die oog dat dit meegehelp het om die mensheid te ontkersten. En so het dit self die vakuum geskep, waarin die Nasionaal-Sosialisme, die Fascisme en die Kommunisme die also ontwortelde massas ' $n$ nuwe binding en 'n nuwe lewensvulling belowe.

Vir hierdie vakuum het die goedwillende en goedbedoelende voorstanders van Unesco in die Angelsaksiese lande blykbaar geen oog nie. Hoe dit ook sy, op die vasteland van Europa het daar gedurende die laaste dekades in die liberale humanistiese lewens- en wêreldbeskouing 'n algemene vervalproses ingetree waaruit nuwe anti-humanistiese magte (Marxisme, Darwinisme en Nietzsche se leer van die Ubermensch) opgkom het. Deur die eerste wêreld oorlog het hierdie innerlike vervalproses sterk in tempo toegeneem. Kommunisme, Fascisme en Nasionaal-Sosialisme kom op en die beide stel teenoor die humanistiese ,ideologie” hulle religieuse „mite van die twintigste eeu". Die reaksionêre en diep antichristelike magte van Nasiïsme en Fascisme is in die jongste wêreldoorlog, altans op staatkundige terrein, gebreek sodat nog net die Kommunisme, wat sy donker, onheilspellende en dreigende skaduwee oor die wêreld werp, oorgebly het. Die opkoms van hierdie magte is juis die bewys dat die breë massas afskeid geneem het van die liberale Humanisme en dis onwaarskynlik dat hulle tot die verouderde ideë sal terugkeer. Hiervan verwag hulle geen besieling meer nie. Hulle is magteloos.

Wie die oog vol verwagting op die nuwe V.V.O. en sy geestes- en geestelike kind Unesco vir die verwerkliking van die vrede rig, moet bedink dat hierdie nog uiters labiele organisasie uitsluitend lewe by die genade van 'n duursame akkoord tussen die vier groot politieke magte, wat voorlopig allermins geneentheid vertoon om hulle skerp belangeteenstellinge te bemantel. Hy moet bedink dat selfs in die allergunstigste geval nog slegs 'n soort wêreldstaat verwerklik kan word, wat sal moet steun op die swaardmag van daardie moontheid wat daarin sal slaag om deur wapengeweld die ander te oorweldig. Hierdie vooruitsig is ver, ver van aanloklik. Dit roep die skrikbeeld op van die apokaliptiese wêreldheerser, wat in sy tirannie alle vryheid- ook die intellektuele en morele vryheid- sal verstik, maar vir wie daar ook die veskriklike endoordeel van God wag!

Daarenteen sal die verlossing en die redding van die mensheid, en daarmee die vrede, kom deur Hom wat op die wit perd sit met die oorwinningskrans op die hoof, met die boog in die hand, en nie met die swaard nie 
(Op. 6:2), waardeur versinnebeeld word dat dit by hierdie ruiter nie gaan om te dood nie, maar om die hart van die mens te tref, die mens wil te oorwin, maar nie om hom te laat omkom nie, dog inteendeel om hom te behou. Daarby word dan gesê dat Hy uitgaan as 'n oorwinnaar en om te oorwin, want aan Hom is alle mag gegee in die hemel en op aarde. In Openb. 19 verskyn $\mathrm{Hy}$ wel met die swaard om die nasies te slaan-wanneer die tyd van genade verby is en die eindoordeel aangebreek het. „In die Christendom die heil ook vir die teenwoordige lewe - hier en nou - . Steeds is teleurstelling en ondergang die lot van volke en rigtinge wat 'n ander god aanhang as die God van die Skrifte (1). En so vrees ons dat Unesco sy pretensie om die geestelike dryfkrag van die V.V.O. te wees, nie in werklikheid sal kan omsit nie!

Potchefstroom.

D. C. S. DU Preez.

(1) Prof. L. J. du Plessis: ..In die Christendom die heil ook vir die teenwoordige lewe-hier en nou". ..Koers." Augustus 1948. 